\title{
Levels and Human Health Risk Assessment of Persistent organics, metalloid and Heavy metals in Fish
}

\author{
*I. Tongo and L. Ezemonye \\ ${ }^{1}$ Laboratory of Ecotoxicology and Environmental Forensics, Department of Animal and Environmental Biology, Faculty of Life Sciences, \\ University of Benin, Nigeria
}

[Corresponding Author: isioma.tongo@uniben.edu]

\begin{abstract}
Concentrations of Persistent organics (Polycyclic aromatic hydrocarbons (PAHs), polychlorinated biphenyls (PCBs), metalloid (As) and heavy metals ( $\mathrm{Fe}, \mathrm{Zn}, \mathrm{Mn}, \mathrm{Cu}, \mathrm{Ni}, \mathrm{Cd} . \mathrm{V}, \mathrm{Cr}, \mathrm{Pb}, \mathrm{Hg}$ ) were measured in fish (Clarias gariepinus) samples collected from selected stations (S1, S2 and S3) along the stretch of Ovia River, Southern Nigeria, to assess the potential risks to humans consuming fish from the river. Acenaphthylene (AcPY), PCB 18 and iron (Fe) were the most dominant residues with mean concentrations ranging from 0.002 to $0.128,0.001$ to 0.003 and 175.97 to $255.52 \mathrm{mg} / \mathrm{kg}$ respectively. The most carcinogenic $\mathrm{PAH}$, Benzo(a)pyrene (BaP) in S3, all the PCB congeners, cadmium $(\mathrm{Cd})$, and lead $(\mathrm{Pb})$ concentrations in the three stations were observed to be above EU recommended guideline values for food safety. Concentrations of dioxin-like PCB congeners, 77, 105, 114 and the sum of carcinogenic PAHs also contributed to the toxic burden of these contaminants in fish. The estimated cumulative THQ for the assessed metalloid and heavy metals indicates health risks from exposure to metalloid and Heavy metals through fish consumption.
\end{abstract}

Keywords: Fish, PAHs, PCBs, Metalloid, Heavy metals, Health Risk

\section{INTRODUCTION}

Human exposure to environmental contaminants including Polycyclic aromatic hydrocarbons (PAHs), polychlorinated biphenyls (PCBs), metalloids and heavy metals occurs primarily from eating food contaminated with these chemicals (Copat et al., 2012). These contaminants have been reported to occur in various foods including meat, fruits, vegetables, oils and fish (Tongo et al, 2017).

Fish constitutes an important source of protein, minerals, and vitamins. It is highly sort after as an alternative to meat, and is a major constituent of most local diet. Catfish (Clarias gariepinus) in particular, is an important source of protein, vitamin D and omega- 6 fatty acids. In Nigeria, catfish is common in many household diets. However, varying levels of contaminants have been reported in catfish (Cheung et al., 2007; Tongo et al., 2017). PAHs, PCBs, metalloids and Heavy metals are among such contaminants that have been reported in fish ( $\mathrm{Li}$ et al., 2008; Copat et al., 2012; Tongo et al., 2017).They represent a group of highly toxic compounds that are ubiquitous with mutagenic and carcinogenic potentials ( Li et al., 2008; Copat et al., 2012; Tongo et al., 2017). Consequently, potential health risks to humans from dietary exposure to these contaminants, especially through fish consumption continue to raise concerns. Health risks resulting from dietary intake of PAHs, PCBs, and heavy metals are frequently assessed using human intake models (USEPA, 2000) and have proven useful in human health risk assessment studies (US EPA, 2000).

The Ovia River is one of the largest inland water bodies in Southern Nigeria composed of fresh and brackish environments that support a large variety of plant and animal species. Economically, the river provides water for fishing, irrigation, urban, domestic and industrial activities. Fishing is a local occupation of people living around this costal environment. Rapid urbanization and agricultural activities around the Ovia River, has caused anthropogenic vulnerability as it receives considerable pollutants from land-based sources (Imoobe and Adeyinka, 2009). Such activities expose fish from this ecological zone to contaminants hence posing a potential health risk to the local population 


\section{Tongo and Ezemonye: Levels and Human Health Risk Assessment of Persistent organics, metalloid}

This study aim to assess the contamination levels of PAHs, PCBs, metalloid and heavy metals in Clarias gariepinus species of fish from Ovia River, Southern Nigeria and to quantify the daily dietary intake of PAHs, PCBs, metalloid and heavy metals from fish consumption and to assess the possible health risk associated with fish consumption.

\section{MATERIALS AND METHODS}

\section{Chemicals, Reagents and Equipment}

All solvents used for this study were of analytical grade and were purchased from Sigma-Aldrich Co. USA. A Standard PAH mixture (17 compounds specified on EPA Method 610) containing, naphthalene, 2-methylnaphthalene, acenaphthylene, acenaphthene, fluorene, phenanthrene, anthracene, fluoranthene, pyrene, benzo(a)anthracene, chrysene, benzo(k)fluoranthrene, benzo(a)pyrene, benzo(b)fluoranthrene, indeno(1,2,3) perylene, dibenzo(a,h)anthracene, and benzo(g,h,i)perylene was also purchased from Sigma-Aldrich Co.USA. Dichloromethane and hexane were supplied by Fisher Chemicals (USA). The GC-FID system consist of a Hewlett-Packard HP-5890 Series gas chromatography (GC) equipped with a flame ionization detector (FID).

\section{Study area}

Ovia River is an ecologically and an economically important inland water body in Southern, Nigeria. The river drains into the Benin River and empties into the Atlantic Ocean (Imoobe and Adeyinka, 2009). Three sampling stations, $\mathrm{S} 1\left(6^{\circ} 33^{\prime} 3.62^{\prime \prime} \mathrm{N}\right.$ and $5^{\circ} 31^{\prime} 12.05^{\prime \prime}$ E), S2 (6 $6^{\circ} 29^{\prime} 4.30^{\prime \prime} \mathrm{N}$ and $\left.5^{\circ} 27^{\prime} 51.05^{\prime \prime} \mathrm{E}\right)$, and $\mathrm{S} 3\left(6^{\circ}\right.$ $10^{\prime} 57.62^{\prime \prime} \mathrm{N}$ and $5^{\circ} 21^{\prime} 43.63^{\prime \prime} \mathrm{E}$ ) were chosen along the stretch of the river. The sampling stations were selected to incorporate sites with fishing activities, anthropogenic impacts, and accessibility. Locations of the sampling stations are shown in Figure 1.

\section{Fish Selection, Collection, and treatment}

Catfish (C. gariepinus) were caught using hand fishing net from three locations (S1, S2 and S3) along the stretch of the river for a period of six (6) months. Samples were collected each month in triplicates from each of the stations. All fishes were weighed $(\mathrm{g})$ and washed to remove dirt, then wrapped in aluminum foil and transported to the laboratory in polythene bags, where they were refrigerated at $4{ }^{\circ} \mathrm{C}$ until extraction.

\section{Analytical procedures}

Analytical procedures for PAHs, PCBs and heavy metals used in this study have been described previously (US EPA, 1986, Llobet et al., 2003; Copat et al., 2012). Organics present in fish samples were extracted according to method of Miglioranza et al. (2003). Prior to extraction, twenty-five grams of whole body tissues were homogenized with anhydrous sodium sulfate and Soxhlet extracted with dichloromethane and $n$-hexane (1:1 v/v) for $8 \mathrm{~h}$. Lipid content was gravimetrically determined while the contaminants fraction was further purified with a silica gel column following the detailed procedure described by Connell et al. (2003). Each fraction was reduced to $100 \mathrm{~mL}$. Quantitative PCBs analysis was done using a Hewlett-Packard (hp) 5890 Series II GC equipped with $63 \mathrm{Ni}$ electron capture detector (ECD) and nitrogen as the carrier gas following an adapted procedure of EPA Method 8081a. The GC column employed was a low polar HP-column of $30 \mathrm{~m}$ length with $0.25 \mathrm{~mm}$ film thickness.

The oven was programmed from $150^{\circ} \mathrm{C}$ ( 5 mins hold) to $300{ }^{\circ} \mathrm{C}\left(4^{\circ} \mathrm{C} / \mathrm{min}\right)$. Nitrogen was used as a carrier gas in constant flow mode $(1 \mathrm{~mL} / \mathrm{min})$. The injector port temperature was programmed at $250^{\circ} \mathrm{C}$ while the $\mathrm{ECD}$ temperature was $300^{\circ} \mathrm{C}$. Quantification was performed using an external standard calibration mixture containing the selected congeners.

For PAH analysis, fish sample analysis was performed using gas chromatography (GC, Hewlett-Packard HP5890 Series II with flame ionization detection (GCFID)). The operations conditions were as follows: initial temperature of $60^{\circ} \mathrm{C}$ for $2 \mathrm{~min}$ and ramped at $25^{\circ} \mathrm{C} / \mathrm{min}$ to $300^{\circ} \mathrm{C}$ for $5 \mathrm{~min}$ and allowed to stay for $15 \mathrm{~min}$ giving a total of run time of $22 \mathrm{~min}$. The florisil SPE method was used to clean up the extracts. A fused silica DB-5MS capillary column $(30 \mathrm{~m} \times 0.32 \mathrm{~mm}$ i.d., $0.25-\mu \mathrm{m}$ film thickness) was used. A standard mixture of 17 priority PAHs (naphthalene, 2methylnaphthalene, acenaphthylene,acenaphthene, fluorene, phenanthrene, anthracene, fluoranthene, pyrene, benzo(a)anthracene, chrysene, benzo(k)fluoranthrene, benzo(a)pyrene, benzo(b)fluoranthrene, indeno(1,2,3) perylene, dibenzo(a,h)anthracene, and benzo(g,h,i)perylene) was obtained and used for the analysis. Compounds were identified by comparing the retention time of 


\section{Nigerian Journal of Basic and Applied Science (month, $\mathbf{x x}$ ), $\mathbf{x x}(\mathbf{x}): \mathbf{x x - x x}$}

standards with that obtained from the extracts, and individual analysis of PAHs was used for quantitation. Individual PAHs were subjected to recommended quality control methods. An analytical blank and spiked sample containing all reagents was run with every 10 samples to assess interference and crosscontamination. The method detection limit (MDL) for all the analyzed PAHs ranged from 0.0001 to $0.003 \mu \mathrm{g} / \mathrm{L}$ (water), $0.001-0.003 \mu \mathrm{g} / \mathrm{kg} \mathrm{dw}$ (sediment), and 0.001$0.003 \mu \mathrm{g} / \mathrm{kg} \mathrm{ww}$ (fish). The overall efficiency of the analytical method was determined by recovery of internal standard, and the average recoveries ranged from 78 to $102 \%$.

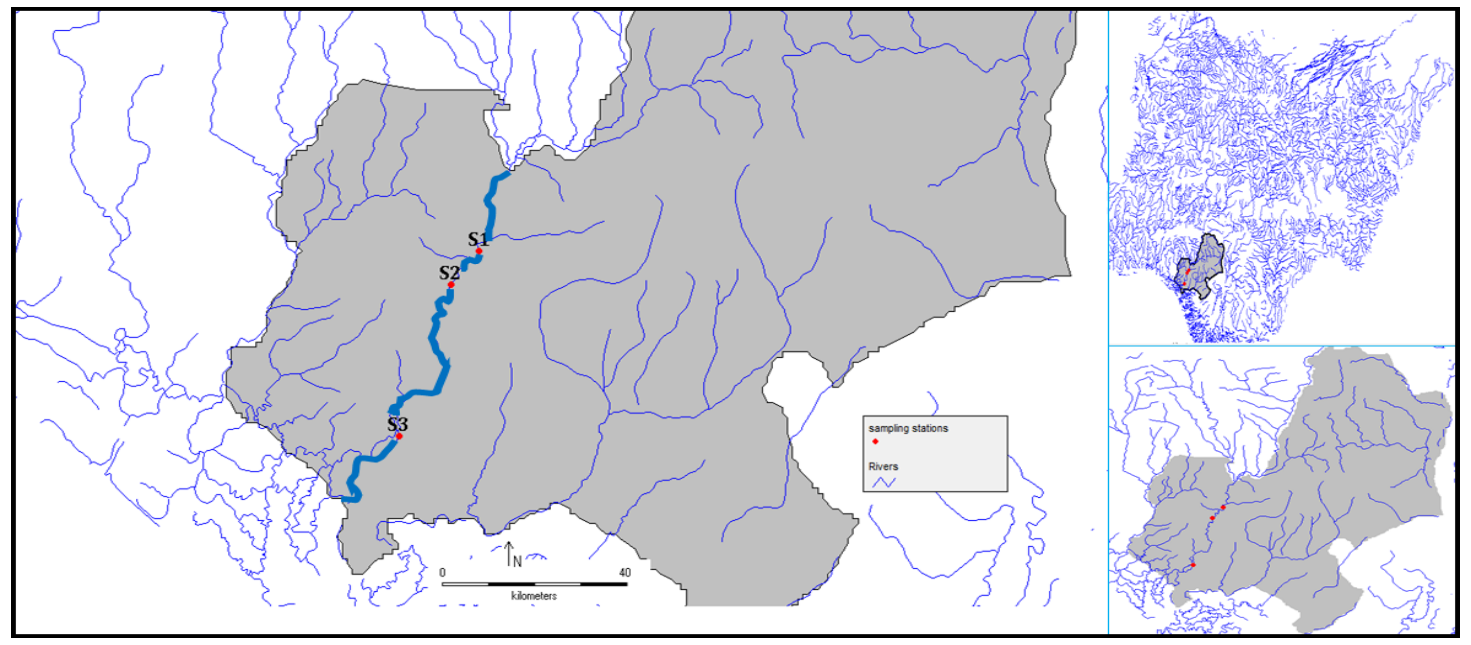

Figure 1: Map of Ovia River showing sampling stations

For metalloid and heavy metal analysis, fish samples were digested according to standard procedures (Novozamsky et al., 1983). Prior to digestion, samples were dried for three days in an oven at $65^{\circ} \mathrm{C}$ to obtain a constant dry weight of $1.0 \mathrm{~g}$. The sample $(1.0 \mathrm{~g})$ was digested using a mixture of $\mathrm{H}_{2} \mathrm{O}_{2}$ and $\mathrm{HNO}_{3}$ in a 1:3 ratio at $150^{\circ} \mathrm{C}$ for 20 min and allowed to cool at room temperature. After digestion, the residues were diluted to a total of $50 \mathrm{ml}$ with $\mathrm{HNO}_{3}$. The digest was finally filtered through $0.45 \mu \mathrm{m}$ micropore membrane filter paper for analysis. Determination and quantification of the heavy metals was done in triplicates using Atomic Absorption Spectrophotometer (AAS).

\section{Human Health Risk Assessment}

Human health risk assessment was carried out to estimate the nature and probability of adverse health effects in humans as a result of exposure to PAHs, PCBs, and heavy metals through consumption of contaminated fish. All calculations were done based on USEPA standards (USEPA, 1996). Assessment was carried out for adults $(70 \mathrm{~kg})$ for both non-carcinogenic and carcinogenic health risk. The description and values of the parameters used for the various calculations are presented in Table 1.

Estimated daily intake (EDI)-The estimated daily intake (EDI) (mg/kg/day) of PAHs, PCBs, and heavy metals were calculated with Equation 1.

Estimated Daily Intake $(\mathrm{EDI})=\frac{C f X I F R}{B W}$

\section{Assessment of non-carcinogenic health risks}

Assessment of non-carcinogenic health risks was achieved by estimating the hazard quotient (HQ). For non-carcinogenic risks from exposure to PCBs and PAHs, the $\mathrm{HQ}$ was calculated as the quotient between the EDI and the reference dose (RfD) (Equation 2), while for heavy metals, the Target Hazard quotient was estimated using Equation 3.

Hazard Quotient (HQ Non-carcinogenic) $=\frac{E D I}{R f D}$

Target Hazard Quotient $(\mathrm{THQ})=\frac{E F X E D X I F R X C f}{R f D X B W \times A T n}$ 
Tongo and Ezemonye: Levels and Human Health Risk Assessment of Persistent organics, metalloid.

Table 1: Parameters used for estimating exposure assessment through Fish Consumption

\begin{tabular}{llll}
\hline Parameters & Unit & Value & Reference \\
\hline Mean concentration of PAHs in Fish & $\mathrm{mg} / \mathrm{kg}$ & Table 2 & Table 2 \\
Reference Dose (RfD) & $\mathrm{mg} / \mathrm{kg} /$ day & USEPA, 1993 & USEPA, 1993 \\
Fish ingestion rate (IFR) & $\mathrm{Kg} / \mathrm{capita} / \mathrm{day}$ & 0.0548 & $\mathrm{FAO}, 2014$ \\
Exposure Duration (ED) & years & 70 & Qu et al., 2015 \\
Exposure Frequency (EF) & Days/year & 365 & Qu et al., 2015 \\
Adult body weight (BW) & $\mathrm{kg}$ & 70 & Tongo et al., 2017 \\
Average life span (ATn) & days & 25550 & Papadakis et al., 2015 \\
Oral Slope Factor (SF) & $\mathrm{mg} / \mathrm{kg} /$ day & US EPA 2005 & US EPA, 2005 \\
Maximum acceptable risk level (RL) & dimensionless & $10^{-5}$ & US EPA, 2000 \\
Toxicity equivalence factor (TEFi) & No Unit & Nisbet and LaGoy, Nisbet and LaGoy, \\
& & 1992; EU, 2006 & 1992; EU, 2006 \\
\hline
\end{tabular}

\section{Assessment of Carcinogenic health risks}

$H Q$ values for carcinogenic risks for PAHs and PCBs were estimated using Equation 4 (USEPA 2005). For heavy metals, $\mathrm{HQ}$ values for carcinogenic risks were estimated using equation 5. The CDI (chronic daily intake) was estimated using equation 6.Carcinogenic risks could only be computed for Arsenic (since As was the only assessed metal with available Slope factor (USEPA, 1993)).

Hazard Quotient $(\mathrm{HQ}$ Carcinogenic $)=E D I X S F$ (4)

Hazard Quotient $(\mathrm{HQ}$ Carcinogenic) $=$ CDI X SF (5)

Chronic daily intake $(\mathrm{CDI})=\frac{E D I X E F \quad X E D}{A T n}$

The hazard index, which estimates the total risk from multiple contaminant pathways, was obtained by summing the $\mathrm{HQ}$ of each contaminant pathway (Equation 7). Risk was evaluated for both noncarcinogenic and carcinogenic risks. Values of $\mathrm{HQ}$ and $\mathrm{HI}$ of contaminants less than one (1) are considered as safe.

$\mathrm{HI}=\sum_{i=1}^{n} H Q i$

The potency of PAHs and PCBs to cause carcinogenic health risk was further evaluated using Carcinogenic Toxic Equivalents (TEQs). This was determined as the sum of the product of the concentrations of individual $\mathrm{PAH}$ congeners or $\Sigma \mathrm{PCBs}$ and their toxicity equivalency factor (TEF) (Equation 8).

Carcinogenic toxic equivalents (TEQs) = $\sum P A H i$ or $\sum P C B i X T E F i$ $=\sum \mathrm{B}(\mathrm{A})$ Pteq or $\left(\sum P C B i X T E F i\right)$

\section{Screening Value Determination}

The screening value (SV) is the threshold concentration of contaminants in edible tissue that is of potential public health concern (Cheung et al., 2007; Wu et al., 2012). The screening values calculated were used to identify potential chemical compounds of concern. The US EPA document (US EPA, 1995) was used in developing the contaminant screening values for both non-carcinogenic and carcinogenic risks. SV values were calculated using Equation 9 and 10.

Screening Value (SV Non-carcinogenic) $=\frac{R f D X B W}{I F R}$ (9)

Screening Value (SV Carcinogenic) $=\frac{((R L / S F) X B W)}{I F R}$ (10)

\section{Statistical analysis}

Data analysis was performed using Microsoft Excel 7.0 programme and Statistical version 8.0. Individual PAHs. The Total PAHs concentrations were summarized separately for each sample station using descriptive statistics (means, range, standard deviation, standard error). Statistical differences in $\mathrm{PAH}$ concentrations between stations, individual PAHs and total PAHs were performed using Analysis of variance (ANOVA) at 0.05 level of significance.

\section{RESULTS AND DISCUSSION}

Concentrations of PAHs in fish (Clarias gariepinus) from Ovia River

Quantitative results of fish tissue analysis for PAHs, PCBs, metalloid and heavy metals residues are presented in Table 2. The total mean PAH 
concentrations in fish ranged from $0.01 \mathrm{mg} / \mathrm{kg}$ at $\mathrm{S} 1$ to $0.92 \mathrm{mg} / \mathrm{kg}$ at S3, the downstream station of the river (Table 2). The total mean for carcinogenic PAHs (sum of $\mathrm{BaA}, \mathrm{Chr}, \mathrm{BkFL}, \mathrm{BaP}, \mathrm{BbFL}$, Ind, DBA, BP) in the fish samples ranged from $0.0002 \mathrm{mg} / \mathrm{kg}$ at $\mathrm{S} 1$ to 0.06 $\mathrm{mg} / \mathrm{kg}$ at S2 and S3 stations (Table 2). The Total PCB levels in fish samples varied from 0.002 to 0.026 $\mathrm{mg} / \mathrm{kg}$ (Table 2). PCB concentrations in fish samples $(0.026 \mathrm{mg} / \mathrm{kg})$ caught from S3, the downstream portion of the river and site of the highest anthropogenic impact, were significantly higher $(P<0.05, F=19.0)$ than S1 $(0.002 \mathrm{mg} / \mathrm{kg})$ and S2 $(0.021 \mathrm{mg} / \mathrm{kg})$ (Table 2).Mean concentrations of metalloid and heavy metal residues in the fish samples from the different stations are shown in Tables 2.

With increasingly intense urbanization around the Ovia River, the amount of PAHs, PCBs, metalloid and heavy metals detected is likely related to anthropogenic activities around the river. These stations sampled receive effluents from domestic, municipal and industrial activities which were observed during sampling. These sources of pollution connected to anthropogenic activities around river catchments are generally known to be sources of PAHs, PCBs, metalloids and heavy metals (Jaward et al., 2012).

The highest levels of benzo(a)pyrene were found in S3 and the mean BaP concentrations exceeded the EU recommended safe limit of $0.002 \mathrm{mg} / \mathrm{kg}$ ww for human fish consumption (EU, 2006), PCB concentrations in the fish samples were above the EU's recommended safe limit of $0.000008 \mathrm{mg} / \mathrm{kg}$ wet weight for the Sum of dioxins and dioxin-like PCBs in muscle meat of fish (EU, 2006) while mean $\mathrm{Pb}$ and $\mathrm{Cd}$ fish concentrations in all the stations sampled were above the maximum allowable limits of 0.30 and $0.05 \mathrm{mg} / \mathrm{kg}$ respectively which calls for serious health concerns.

\section{Human health Risk Assessment}

Human exposure to PCBs is principally through diet, especially via fish from contaminated waters (Tard et al., 2007). Food consumption has been the major source of PCBs body burden in humans (ATSDR, 2000). The estimated daily intake of PAHs, PCBs, and heavy metals in fish samples from the different stations are shown in Table 3.
Estimated intake of PAHs, PCBs, Metalloid and Heavy metals through fish consumption-

The estimated daily intake of PAHs, PCBs, metalloid and heavy metals in fish samples from the different stations are shown in Table 3. The average intake (mg/kg body weight/day) of PAHs through fish consumption was estimated to be 0 to $1.4 \mathrm{E}-06,3.9 \mathrm{E}$ 07 to $3.8 \mathrm{E}-05$ and $1.3 \mathrm{E}-07$ to $1.3 \mathrm{E}-04$ for $\mathrm{S} 1, \mathrm{~S} 2$ and S3 respectively (Table 3$)$. Estimated EDI $(\mathrm{mg} / \mathrm{kg}$ body weight/day) for PCBs ranged from 0 to $7.8 \mathrm{E}-07$ in S1, $1.2 \mathrm{E}-06$ to $3.1 \mathrm{E}-06$ in $\mathrm{S} 2$ and $5.9 \mathrm{E}-07$ to $3.6 \mathrm{E}-06$ in S3. EDI ( $\mathrm{mg} / \mathrm{kg}$ body weight/day) values for the metalloid and heavy metals in S1, S2 and S3 ranged from 0 to $0.155,0$ to $0.200,0$ to 0.138 respectively. Fish species caught downstream (S3) contributed to the highest intake of total PAHs and PCBs while fish species caught in S2 has the highest EDI values for heavy metals. Carcinogenic PAHs accounted for $10.7 \%$ of the estimated daily intake of PAHs in the fish species. Varying estimates for daily intake of PAHs, PCBs, and heavy metals from fish consumption have been reported in other countries (PCBs- Spain $(92$ $\mathrm{g} / \mathrm{kg} / \mathrm{d}$, Llobet et al., 2003), China (1.62 ng/kg/d, Li et al., (2008)), PAHs- India (1.77 -10.7 mg/kg/d, Dhananjayan and Muralidharan, 2012), Korea (13.8$16.7 \mathrm{ng} / \mathrm{kg}$ body weight/d, Moon et al., 2010), Heavy metals - Sicily $(0.007-0.503 \mu \mathrm{g} / \mathrm{kg} / \mathrm{d}$, Copat et al., 2012). Variations in results seem to be associated with the consumption rate of fish, body weight and accumulation level of the contaminants in the fish.

The estimated daily intake of PAHs, PCBs, and heavy metals were however observed to be lower than the reference dose (RfD) indicating low risk through fish consumption.

\section{Non-carcinogenic health risks assessment}

The averages $H Q$ for $P A H s, P C B s$, and $T H Q$ for Heavy metals in fish samples for non-carcinogenic health risk are shown in Tables 4-6. Estimated Hls for PAHs, PCBs and heavy metals were $0.008,0.63$ and 1.60 respectively (Tables 4-6). Estimated $\mathrm{HQ}$ and $\mathrm{HI}$ values for PAHs and PCBs were below 1, indicating that exposure to either individual PAHs or complex $\mathrm{PAH}$ and $\mathrm{PCB}$ mixtures through fish consumption would have no potential negative health effect on consumers. 
Tongo and Ezemonye: Levels and Human Health Risk Assessment of Persistent organics, metalloid

Table 2: Mean Concentrations (mg/kg) of PAHs, PCBs, Metalloid and Heavy metals residues in Fish from Ovia River

\begin{tabular}{|c|c|c|c|c|c|c|c|c|c|c|c|}
\hline \multicolumn{4}{|c|}{ PAHs (mg/kg) } & \multicolumn{4}{|l|}{ PCBs } & \multicolumn{4}{|c|}{ Heavy Metals } \\
\hline & S1 & S2 & S3 & & S1 & S2 & S3 & & S1 & S2 & S3 \\
\hline $\mathrm{NaP}$ & $0.00 \pm 0.00$ & $0.03 \pm 0.05$ & $0.13 \pm 0.29$ & PCB7 & $0.00 \pm 0.00$ & $0.00 \pm 0.00$ & $0.00 \pm 0.00$ & $\mathrm{Fe}$ & $198.60 \pm 39.49$ & $255.52 \pm 71.12$ & $175.97 \pm 27.00$ \\
\hline 2-MNaP & $0.00 \pm 0.00$ & $0.03 \pm 0.05$ & $0.02 \pm 0.03$ & PCB18 & $0.00 \pm 0.00$ & $0.00 \pm 0.01$ & $0.00 \pm 0.00$ & $\mathrm{Zn}$ & $78.65 \pm 24.39$ & $109.38 \pm 32.34$ & $79.39 \pm 14.87$ \\
\hline AcPY & $0.00 \pm 0.00$ & $0.05 \pm 0.08$ & $0.15 \pm 0.24$ & PCB28 & $0.00 \pm 0.00$ & $0.00 \pm 0.00$ & $0.00 \pm 0.00$ & $\mathrm{Mn}$ & $13.31 \pm 4.64$ & $17.37 \pm 8.29$ & $9.61 \pm 3.39$ \\
\hline $\mathrm{AcP}$ & $0.00 \pm 0.00$ & $0.01 \pm 0.00$ & $0.16 \pm 0.35$ & PCB52 & $0.00 \pm 0.00$ & $0.00 \pm 0.00$ & $0.00 \pm 0.00$ & $\mathrm{Cu}$ & $8.73 \pm 3.35$ & $9.92 \pm 6.94$ & $5.55 \pm 3.12$ \\
\hline Flu & $0.00 \pm 0.00$ & $0.01 \pm 0.01$ & $0.10 \pm 0.14$ & PCB43 & $0.00 \pm 0.00$ & $0.00 \pm 0.00$ & $0.00 \pm 0.00$ & $\mathrm{Ni}$ & $12.45 \pm 1.37$ & $13.50 \pm 3.61$ & $8.40 \pm 0.90$ \\
\hline Phe & $0.00 \pm 0.00$ & $0.00 \pm 0.00$ & $0.01 \pm 0.01$ & PCB60 & $0.00 \pm 0.00$ & $0.00 \pm 0.00$ & $0.00 \pm 0.00$ & $\mathrm{Cd}$ & $0.89 \pm 0.51$ & $0.85 \pm 1.00$ & $0.38 \pm 0.52$ \\
\hline Ant & $0.00 \pm 0.00$ & $0.01 \pm 0.01$ & $0.09 \pm 0.20$ & PCB77 & $0.00 \pm 0.00$ & $0.00 \pm 0.00$ & $0.00 \pm 0.00$ & V & $2.42 \pm 0.65$ & $2.00 \pm 0.65$ & $2.63 \pm 1.47$ \\
\hline $\mathrm{FL}$ & $0.00 \pm 0.00$ & $0.01 \pm 0.01$ & $0.17 \pm 0.28$ & PCB101 & $0.00 \pm 0.00$ & $0.00 \pm 0.00$ & $0.00 \pm 0.00$ & $\mathrm{Cr}$ & $0.82 \pm 0.16$ & $0.89 \pm 0.39$ & $0.52 \pm 0.10$ \\
\hline Pyr & $0.00 \pm 0.00$ & $0.01 \pm 0.03$ & $0.03 \pm 0.06$ & PCB105 & $0.00 \pm 0.00$ & $0.00 \pm 0.00$ & $0.01 \pm 0.01$ & $\mathrm{~Pb}$ & $1.42 \pm 0.56$ & $1.36 \pm 1.17$ & $0.51 \pm 0.66$ \\
\hline $\mathrm{BaA}$ & $0.00 \pm 0.00$ & $0.00 \pm 0.00$ & $0.02 \pm 0.03$ & PCB114 & $0.00 \pm 0.00$ & $0.00 \pm 0.00$ & $0.00 \pm 0.00$ & $\mathrm{Hg}$ & $0.00 \pm 0.00$ & $0.00 \pm 0.00$ & $0.00 \pm 0.00$ \\
\hline Chr & $0.00 \pm 0.00$ & $0.03 \pm 0.06$ & $0.01 \pm 0.01$ & PCB153 & $0.00 \pm 0.00$ & $0.00 \pm 0.00$ & $0.00 \pm 0.00$ & As & $0.00 \pm 0.00$ & $0.00 \pm 0.00$ & $0.00 \pm 0.00$ \\
\hline BkFL & $0.00 \pm 0.00$ & $0.03 \pm 0.07$ & $0.03 \pm 0.07$ & $\sum P C B$ & $0.00 \pm 0.01$ & $0.02 \pm 0.01$ & $0.03 \pm 0.02$ & $\sum H M$ & $317.29 \pm 66.84$ & $410.79 \pm 117.81$ & $282.95 \pm 52.03$ \\
\hline $\mathrm{BaP}$ & $0.00 \pm 0.00$ & $0.00 \pm 0.00$ & $0.00 \pm 0.01$ & & & & & & & & \\
\hline $\mathrm{BbFL}$ & $0.00 \pm 0.00$ & $0.00 \pm 0.00$ & $0.00 \pm 0.00$ & & & & & & & & \\
\hline Ind & $0.00 \pm 0.00$ & $0.00 \pm 0.00$ & $0.00 \pm 0.00$ & & & & & & & & \\
\hline DBA & $0.00 \pm 0.00$ & $0.00 \pm 0.00$ & $0.00 \pm 0.00$ & & & & & & & & \\
\hline BP & $0.00 \pm 0.00$ & $0.00 \pm 0.00$ & $0.00 \pm 0.00$ & & & & & & & & \\
\hline$\sum \mathrm{PAH}$ & $0.01 \pm 0.01$ & $0.21 \pm 0.17$ & $0.92 \pm 0.52$ & & & & & & & & \\
\hline$\sum \mathrm{CPAH}$ & $0.00 \pm 0.00$ & $0.06 \pm 0.08$ & $0.06 \pm 0.08$ & & & & & & & & \\
\hline
\end{tabular}

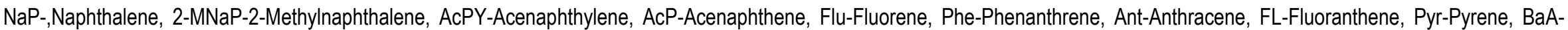

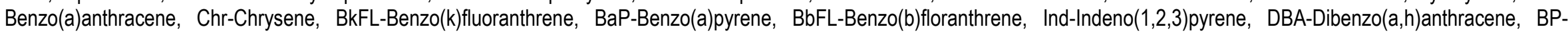
Benzo(g,h,i,)perylene, $\Sigma$ PAH-Sum of Total PAH, $\Sigma$ PAH-Sum of Total Carcinogenic PAH.

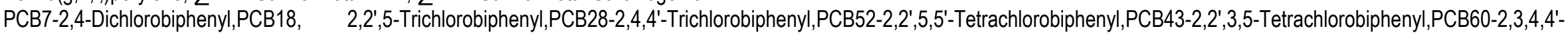
Tetrachlorobiphenyl,PCB77-3,3',4,4'-Tetrachlorobiphenyl,PCB101-2,2',4,5,5'-Pentachlorobiphenyl,PCB105-2,3,3',4,4'-Pentachlorobiphenyl,PCB114-2,3,4,4',5-

Pentachlorobiphenyl,PCB153-2,2',4,4',5,5'-Hexachlorobiphenyl, $\sum$ PCB-Total PCBs.

Fe-Iron, Zn-Zinc, Mn-manganese, Cu-Copper, Ni-Nickel, Cd- Cadmium,V-Vanadium, Cr-Chromium, Pb-Lead, Hg-Mercury, As-Arsenic, $\sum$ HM-Total Heavy Metals. 
Table 3: Estimated daily intake(mg/kg body weight/day) of PAHs, PCBs, Metalloid and Heavy metals for adult (70-kg body weight) through consumption of fish from Ovia River

\begin{tabular}{|c|c|c|c|c|c|c|c|c|c|c|c|}
\hline \multicolumn{4}{|c|}{$\mathrm{PAH}(\mathrm{mg} / \mathrm{kg}$ body weight/day) } & \multicolumn{4}{|c|}{ PCB(mg/kg body weight/day) } & \multicolumn{4}{|c|}{ Heavy metals(mg/kg body weight/day) } \\
\hline & S1 & S2 & S3 & & S1 & $\mathrm{S} 2$ & S3 & & S1 & S2 & S3 \\
\hline $\mathrm{NaP}$ & $1.20 \times 10^{-6}$ & $2.20 \times 10^{-5}$ & $1.00 \times 10^{-4}$ & PCB7 & $7.8 \times 10^{-7}$ & $1.50 \times 10^{-6}$ & $1.80 \times 10^{-6}$ & $\mathrm{Fe}$ & 0.155 & 0.200 & 0.138 \\
\hline 2-MNaP & $1.40 \times 10^{-6}$ & $2.10 \times 10^{-5}$ & $1.50 \times 10^{-5}$ & PCB18 & $5.20 \times 10^{-7}$ & $3.10 \times 10^{-6}$ & $2.20 \times 10^{-6}$ & $\mathrm{Zn}$ & 0.062 & 0.086 & 0.062 \\
\hline AcPY & $1.40 \times 10^{-6}$ & $3.80 \times 10^{-5}$ & $1.20 \times 10^{-4}$ & PCB28 & 0.00 & $1.20 \times 10^{-6}$ & $2.30 \times 10^{-6}$ & $\mathrm{Mn}$ & 0.010 & 0.014 & 0.008 \\
\hline AcP & $7.80 \times 10^{-7}$ & $4.40 \times 10^{-6}$ & $1.30 \times 10^{-4}$ & PCB52 & $6.50 \times 10^{-8}$ & $1.60 \times 10^{-6}$ & $2.40 \times 10^{-6}$ & $\mathrm{Cu}$ & 0.007 & 0.008 & 0.004 \\
\hline Flu & $1.30 \times 10^{-6}$ & $6.80 \times 10^{-6}$ & $7.70 \times 10^{-5}$ & PCB43 & 0.00 & $1.80 \times 10^{-6}$ & $2.70 \times 10^{-6}$ & $\mathrm{Ni}$ & 0.010 & 0.011 & 0.007 \\
\hline Phe & $1.00 \times 10^{-6}$ & $2.10 \times 10^{-6}$ & $7.70 \times 10^{-6}$ & PCB60 & 0.00 & $1.60 \times 10^{-6}$ & $2.00 \times 10^{-6}$ & $\mathrm{Cd}$ & 0.001 & 0.001 & 0.000 \\
\hline Ant & $2.60 \times 10^{-6}$ & $7.20 \times 10^{-6}$ & $7.40 \times 10^{-5}$ & PCB77 & $1.30 \times 10^{-7}$ & $1.40 \times 10^{-6}$ & $1.00 \times 10^{-6}$ & V & 0.002 & 0.002 & 0.002 \\
\hline $\mathrm{FL}$ & $6.50 \times 10^{-7}$ & $6.00 \times 10^{-6}$ & $1.30 \times 10^{-4}$ & PCB101 & 0.00 & $1.20 \times 10^{-6}$ & $5.90 \times 10^{-6}$ & $\mathrm{Cr}$ & 0.001 & 0.001 & 0.000 \\
\hline Pyr & $1.30 \times 10^{-7}$ & $1.10 \times 10^{-5}$ & $2.40 \times 10^{-5}$ & PCB105 & 0.00 & $1.20 \times 10^{-6}$ & $3.60 \times 10^{-6}$ & $\mathrm{~Pb}$ & 0.001 & 0.001 & 0.000 \\
\hline $\mathrm{BaA}$ & 0.00 & $2.00 \times 10^{-6}$ & $1.40 \times 10^{-5}$ & PCB114 & $6.50 \times 10^{-8}$ & $1.20 \times 10^{-6}$ & $6.20 \times 10^{-7}$ & $\mathrm{Hg}$ & 0.000 & 0.000 & 0.000 \\
\hline Chr & $1.30 \times 10^{-7}$ & $2.20 \times 10^{-5}$ & $5.60 \times 10^{-6}$ & PCB153 & $6.50 \times 10^{-8}$ & $7.20 \times 10^{-7}$ & $7.80 \times 10^{-7}$ & As & 0.000 & 0.000 & 0.000 \\
\hline BkFL & 0.00 & $2.20 \times 10^{-5}$ & $2.40 \times 10^{-5}$ & $\sum \mathrm{PCBs}$ & $1.60 \times 10^{-6}$ & $1.70 \times 10^{-5}$ & $2.00 \times 10^{-5}$ & $\sum \mathrm{HM}$ & 0.248 & 0.322 & 0.222 \\
\hline $\mathrm{BaP}$ & 0.00 & $7.80 \times 10^{-7}$ & $2.10 \times 10^{-6}$ & & & & & & & & \\
\hline $\mathrm{BbFL}$ & 0.00 & $7.80 \times 10^{-7}$ & $1.20 \times 10^{-6}$ & & & & & & & & \\
\hline Ind & 0.00 & $5.20 \times 10^{-7}$ & $2.60 \times 10^{-7}$ & & & & & & & & \\
\hline DBA & 0.00 & $3.90 \times 10^{-7}$ & $2.60 \times 10^{-7}$ & & & & & & & & \\
\hline BP & 0.00 & $5.20 \times 10^{-7}$ & $1.30 \times 10^{-7}$ & & & & & & & & \\
\hline$\sum \mathrm{PAH}$ & $8.4 \times 10^{-6}$ & $1.70 \times 10^{-4}$ & $7.20 \times 10^{-4}$ & & & & & & & & \\
\hline$\Sigma \mathrm{CPAH}$ & $1.3 \times 10^{-7}$ & $4.80 \times 10^{-5}$ & $4.70 \times 10^{-5}$ & & & & & & & & \\
\hline
\end{tabular}




\section{Tongo and Ezemonye: Levels and Human Health Risk Assessment of Persistent organics, metalloid.}

However, the estimated $\mathrm{HI}$ values for the assessed metals were above 1 (1.60) (Table 5), indicating possible health risk from heavy metal exposure through fish consumption. The mean concentrations of PAHs, PCBs, and heavy metals in all the analysed samples were observed to be lower than the estimated threshold screening values, indicating low risk from consumption of the fish species.

\section{Assessment of Carcinogenic health risks}

Estimated average $H Q$ values for carcinogenic risks, for total PAHs, PCBs and metalloid (arsenic) are presented in Table 6. $\mathrm{HQ}$ values for PAHs ranged from $1.9 \times 10^{7}$ to $6.98 \times 10^{6}, \mathrm{PCBs}-1.04 \times 10^{6}$ to $3.87 \times 10^{6}$ while the $\mathrm{HQ}$ for Arsenic was $2.24 \times 10^{7}$. The total risk from multiple contaminant pathways estimated using the $\mathrm{HI}$ was $1.43 \times 10^{5}, 2.54 \times 10^{5}$ and $2.24 \times 10^{7}$ for PAHs, PCBs and metalloid (arsenic) respectively. Estimated $\mathrm{HQ}$ and $\mathrm{HI}$ values for all the assessed contaminants were below 1 indicating minimal risks from exposure through the consumption of fish from Ovia River. In terms of Individual carcinogenic potencies for PAHs and PCBs, values varied among the different compounds assessed. Among the PAH congeners, Benzo(k)fluoranthrene had the highest carcinogenic potency $(\mathrm{mg} / \mathrm{kg})$ in C. gariepinus $(0.002)$ while for PCBs, PCB 105 had the highest carcinogenic potency $\left(1.38 \times 10^{7}\right)$ (Table 6$)$.

The potency of PAHs and PCBs to cause carcinogenic health risk was further evaluated using Carcinogenic Toxic Equivalents (TEQs). TEQ values were 0.006 and 0.307 for PAHs and PCBs respectively. These values were however observed to be lower than the calculated SV (Table 6), which is the threshold concentration of the contaminants in the fish tissue that is of potential public health concern (Cheung et al., 2007). Results of the calculated SVs indicate that the assessed contaminants in Ovia River were not of potential health concern, and the potential carcinogenic risks from exposure to individual $\mathrm{PAHs}$ and PCBs through fish consumption are low. Estimated $\mathrm{HQ}$ and $\mathrm{HI}$ values for all the assessed contaminants were below 1 indicating minimal risks from exposure through the consumption of fish from Ovia River.

Table 4: Non-Carcinogenic and Carcinogenic Risk of PAHs for adult (70-kg body weight)

\begin{tabular}{|c|c|c|c|c|c|c|}
\hline \multicolumn{7}{|l|}{ PAH } \\
\hline & $H Q$ & $H Q$ & SV & SV & \multirow{2}{*}{\multicolumn{2}{|c|}{ B(A)Pteq }} \\
\hline $\mathrm{NaP}$ & Noncarcinogenic & Carcinogenic & Noncarcinogenic & Carcinogenic & & \\
\hline 2-MNaP & $2.00 \times 10^{-3}$ & $\mathrm{NA}$ & 25.55 & NA & \multicolumn{2}{|l|}{0.00} \\
\hline ACPY & $3.00 \times 10^{-3}$ & NA & 5.11 & NA & \multicolumn{2}{|l|}{0.00} \\
\hline $\mathrm{AcP}$ & NA & NA & NA & NA & \multicolumn{2}{|l|}{0.00} \\
\hline Flu & $1.00 \times 10^{-3}$ & NA & 76.64 & NA & \multicolumn{2}{|l|}{0.00} \\
\hline Phe & $1.00 \times 10^{-3}$ & NA & 51.10 & NA & \multicolumn{2}{|l|}{0.00} \\
\hline Ant & NA & NA & NA & NA & \multicolumn{2}{|l|}{0.00} \\
\hline $\mathrm{FL}$ & 0.00 & NA & 383.21 & NA & \multicolumn{2}{|l|}{0.00} \\
\hline Pyr & $1.00 \times 10^{-3}$ & NA & 51.10 & NA & \multicolumn{2}{|l|}{0.00} \\
\hline $\mathrm{BaA}$ & 0.00 & NA & 38.32 & NA & \multicolumn{2}{|l|}{0.00} \\
\hline $\mathrm{Chr}$ & NA & 0.00 & NA & 0.02 & \multicolumn{2}{|l|}{$1.00 \times 10^{-3}$} \\
\hline BkFL & NA & 0.00 & NA & 1.75 & \multicolumn{2}{|l|}{0.00} \\
\hline $\mathrm{BaP}$ & NA & 0.00 & NA & 0.18 & \multicolumn{2}{|l|}{$2.00 \times 10^{-3}$} \\
\hline $\mathrm{BbFL}$ & NA & $6.98 \times 10^{-6}$ & NA & $2.00 \times 10^{-3}$ & \multicolumn{2}{|l|}{$1.00 \times 10^{-3}$} \\
\hline Ind & NA & $4.76 \times 10^{-7}$ & NA & 0.01 & \multicolumn{2}{|l|}{0.00} \\
\hline DBA & NA & $1.90 \times 10^{-7}$ & NA & 0.01 & \multicolumn{2}{|l|}{0.00} \\
\hline \multirow[t]{3}{*}{$\mathrm{BP}$} & NA & $1.59 \times 10^{-6}$ & NA & $2.00 \times 10^{-3}$ & \multicolumn{2}{|l|}{$2.00 \times 10^{-3}$} \\
\hline & NA & NA & NA & NA & NA & \\
\hline & $\mathrm{HI}-800$ Y $10-3$ & $H I-100$ × $10-5$ & & & \multicolumn{2}{|l|}{$\sum_{0.01} \mathrm{~B}(\mathrm{~A}) \mathrm{Pteq}=\mathrm{TEQ}$} \\
\hline
\end{tabular}

HQ-Hazard Quotient, HI-Hazard Index, SV-Screening Value,B(A)Pteq-Carcinogenic potencies for PAHs, TEQ- Carcinogenic toxic equivalents, NA-Not available. 
Table 5: Non-Carcinogenic and Carcinogenic Risk of Metalloid and Heavy metals for adult (70-kg body weight)

\begin{tabular}{lllll}
\hline Heavy & $\mathrm{HQ}$ & $\mathrm{HQ}$ & $\mathrm{SV}$ & \\
Metals & Noncarcinogenic & Carcinogenic & Noncarcinogenic & SV Carcinogenic \\
\hline $\mathrm{Fe}$ & 0.10 & $\mathrm{NA}$ & 894.16 & $\mathrm{NA}$ \\
$\mathrm{Zn}$ & 0.10 & $\mathrm{NA}$ & 383.21 & $\mathrm{NA}$ \\
$\mathrm{Mn}$ & 0.03 & $\mathrm{NA}$ & 178.83 & $\mathrm{NA}$ \\
$\mathrm{Cu}$ & 0.07 & $\mathrm{NA}$ & 51.10 & $\mathrm{NA}$ \\
$\mathrm{Ni}$ & 0.19 & $\mathrm{NA}$ & 25.55 & $\mathrm{NA}$ \\
$\mathrm{Cd}$ & 0.24 & $\mathrm{NA}$ & 1.28 & $\mathrm{NA}$ \\
$\mathrm{V}$ & 0.79 & $\mathrm{NA}$ & 1.28 & $\mathrm{NA}$ \\
$\mathrm{Cr}$ & 0.08 & $\mathrm{NA}$ & 3.83 & $\mathrm{NA}$ \\
$\mathrm{Pb}$ & $\mathrm{NA}$ & $\mathrm{NA}$ & $\mathrm{NA}$ & $\mathrm{NA}$ \\
$\mathrm{Hg}$ & 0.00 & $\mathrm{NA}$ & 0.38 & $\mathrm{NA}$ \\
$\mathrm{As}$ & 0.00 & 0.000 & 0.38 & 0.01 \\
& $\mathrm{HI}=1.60$ & $\mathrm{HI}=2.24 \times 10^{-7}$ & \\
\hline
\end{tabular}

HQ- Hazard Quotient, HI- Hazard Index, SV-Screening Value, NA-Not available.

Table 6: Non-Carcinogenic and Carcinogenic Risk of PCBs for adult (70-kg body weight)

\begin{tabular}{|c|c|c|c|c|c|}
\hline P CBs & $\begin{array}{l}\mathrm{HQ} \\
\text { Noncarcinogenic }\end{array}$ & $\begin{array}{l}\mathrm{HQ} \\
\text { Carcinogenic }\end{array}$ & $\begin{array}{l}\text { SV } \\
\text { Noncarcinogenic }\end{array}$ & $\begin{array}{l}\text { SV } \\
\text { Carcinogenic }\end{array}$ & $\begin{array}{l}\text { Carcinogenic } \\
\text { Toxic Potency }\end{array}$ \\
\hline PCB7 & 0.07 & 0.000 & 0.03 & 0.01 & $\overline{N A}$ \\
\hline PCB18 & 0.10 & 0.000 & 0.03 & 0.01 & NA \\
\hline PCB28 & 0.06 & 0.000 & 0.03 & 0.01 & NA \\
\hline PCB52 & 0.07 & 0.000 & 0.03 & 0.01 & NA \\
\hline PCB43 & 0.07 & 0.000 & 0.03 & 0.01 & NA \\
\hline PCB60 & 0.06 & 0.000 & 0.03 & 0.01 & NA \\
\hline PCB77 & 0.04 & 0.000 & 0.03 & 0.01 & $1.33 \times 10^{-7}$ \\
\hline PCB101 & 0.03 & 0.000 & 0.03 & 0.01 & NA \\
\hline PCB105 & 0.08 & 0.000 & 0.03 & 0.01 & $1.38 \times 10^{-7}$ \\
\hline PCB114 & 0.03 & 0.000 & 0.03 & 0.01 & $2.38 \times 10^{-7}$ \\
\hline PCB153 & 0.03 & 0.000 & 0.03 & 0.01 & NA \\
\hline \multirow[t]{2}{*}{$\sum \mathrm{PCB}$} & 0.63 & 0.000 & 0.03 & 0.01 & NA \\
\hline & $\mathrm{HI}=0.63$ & $\mathrm{HI}=3 \times 10^{-5}$ & & & $\mathrm{TEQ}=0.31$ \\
\hline
\end{tabular}

HQ- Hazard Quotient, HI- Hazard Index, SV-Screening Value, TEQ- Carcinogenic toxic equivalents, NA-Not available.

\section{CONCLUSION}

Results of this study revealed that the land use activities in surrounding areas would have contributed to increasing levels of contaminants in fish from this Ovia River. The concentrations of PAHs (benzo(a)pyrene), PCBs and heavy metals (Pb and $\mathrm{Cd}$ ) in the assessed fish species were above recommended safe levels for human consumption. The activities around the Ovia River especially downstream should, therefore, be kept under strict surveillance and monitoring of contaminants in fish for human consumption should be done frequently to guarantee safety.

\section{REFERENCES}

Agency for Toxic Substances and Disease Registry ATSDR.(2000). Toxicological profile for Polychlorinated Biphenyls PCBs. Atlanta, GA: U.S. Department of Health and Human Services, Public Health Service.

Cheung, K.C., Leung, H.M., Kong, .K.Y., Wong, M.H. (2007). Residual levels of DDTs and PAHs in freshwater and marine fish from Hong Kong 


\section{Tongo and Ezemonye: Levels and Human Health Risk Assessment of Persistent organics, metalloid}

markets and their health risk assessment, Chemosphere, 66: 460-468.

Connell, D.W., Fung, C.N., Minh, T.B., Tanabe, S., Lam, P.K.S.,Wong, B.S.F., Lama, M.H.W., Wong, L.C., Wu, R.S.S., and Richardson, B.(2003). Risk to breeding success of fish-eating Ardeids due to persistent organic contaminants in Hong Kong: evidence from organochlorine compounds in eggs. Water Research, 37: 459-467.

Copat, C, Bella, F., Castaing, M., Fallico, R., Sciacca, S., and Ferrante, M.(2012). Heavy Metals Concentrations in Fish from Sicily Mediterranean Sea and Evaluation of Possible Health Risks To ConsumersBulletin of Environmental Contamination and Toxicology, 88:78-83.

Dhananjayan, V., and Muralidharan, S. (2012). Polycyclic Aromatic Hydrocarbons in various species of fishes from Mumbai Harbour, India and their Dietary Intake Concentration to Human. International Journal of Oceanography, (2012): 1-6.

European Union Commission Regulation EU. (2006). European Union Commission Regulation EU No 1881/2006 of 19 December 2006. Setting maximum levels for certain contaminants in foodstuff, 2006.

Imoobe, T., and Adeyinka, M.(2009). Zooplanktonbased assessment of the trophic state of a tropical forest river in Nigeria. Archives of Biological Sciences Beograd, 61: 733-740.

Jaward, F.M., Alegria, H.A., Galindo Reyes J.G., Hoare A. (2012). Levels of PAHs in the Waters, Sediments, and Shrimps of Estero de Urias, an Estuary in Mexico, and Their Toxicological Effects. The Scientific World Journal, 2102:1-12.

Li, X., Gan, T., Yang, X., Zhou, J, Dai J. Xu, M. (2008). Human health risk of organochlorine pesticides OCPs and polychlorinated biphenyls PCBs in edible fish from Huairou Reservoir and Gaobeidian Lake in Beijing, China. Food Chemistry, 109:348-354.

Llobet J.M., Bocio, A., Domingo J.I., Teixido, A., Casas, C. and Müller, L. (2003). Levels of Polychlorinated Biphenyls in Foods from Catalonia Spain: Estimated Dietary Intake. Journal of Food Protection, 663: 479-484.

Miglioranza, K.S.B., Aizpún, J.E. and Moreno, V.J. (2003). Dynamics of organochlorine pesticides in soils from a SE region of Argentina. Environmental Toxicology and Chemistry, 22: 712-717.
Moon, H.B., Kim, H.S., Choi, M. and. Choi, H.G. (2010). Intake and potential health risk of polycyclic aromatic hydrocarbons associated with seafood consumption in Korea from 2005 to 2007. Archives of Environmental Contamination and Toxicology, 581: 214-221.

Novozamsky, I., Houba, V.J.G., van Eck, R., and van Vark, W.(1983). A novel digestion technique for multi-element plant analysis. Communications in Soil Science and Plant Analysis, 14: 239-248.

Tard, A., Gallotti, S., Leblanc, J., and Volatier, J.(2007). Dioxins, furans and dioxin-like PCBs: occurrence in food and dietary intake in France. Food Additives and Contaminants, 24(09): 1007-1017.

Tongo, I., Ezemonye, L., and Akpeh, K..(2017). Distribution, characterization, and human health risk assessment of polycyclic aromatic hydrocarbons PAHs in Ovia River, Southern Nigeria, Environmental Monitoring and Assessment, 189:247.

USDA National Agricultural Library. Nutrient Data Laboratory.

(2012)<http://ndb.nal.usda.gov/ndb/foods/show/ 4673?qlookup $=15234 \& f g=\&$ format $=\&$ man $=\& l f a c$ et $=\& \max =25 \&$ new $=1>$ accessed 20.06.12.

US Environmental Protection Agency (USEPA). (1993). Provisional guidance for quantitative risk assessment of polycyclic aromatic hydrocarbons. EPA/600/R-93/089. U.S. Environmental Protection Agency. Washington, DC: Office of Research and Development, 1993.

US Environmental Protection Agency (USEPA).(1996). Quantitative Uncertainty Analysis of Superfund Residential Risk Pathway Models for Soil and Ground water: White Paper. Office of Health and Environmental Assessment, Oak Ridge TN USA. USEPA (2000). Guidance for assessing chemical contaminant. Data for Use in Fish Advisories. Fish sampling and analysis, 3rd ed. Washington DC: Office of Water; 2000. [EPA823-R-95-007].

Wu, W., Ning Qin, N., He, W., He, Q., Ouyang, H., and Xu, F. (2012). Levels, Distribution, and Health Risks of Polycyclic Aromatic Hydrocarbons in Four Freshwater Edible Fish Species from the Beijing Market. The Scientific World Journal, 2012, 1-12. 